\title{
Quality characteristics and antioxidant activities of 'Sulgidduk' added with chicory powder during storage
}

\author{
Hyun Jin $\mathrm{Choi}^{\ddagger}$, Da Hee Kim ${ }^{\ddagger}$, So Yeon Kim, Seung Yeon Baek, \\ $\mathrm{Su}$ Jin Kim, Mee Ree Kim* \\ Department of Food and Nutrition, Chungnam National University, Daejeon 34134, Korea
}

\section{치커리 첨가 설기떡의 저장 중 품질 특성 및 항산화 활성}

\author{
최현진 ${ }^{\ddagger}$ - 김다희 ${ }^{\ddagger}$ 김소연 · 백승연 · 김수진 · 김미리* \\ 충남대학교 식품영양학과
}

\begin{abstract}
The purpose of this study was to determine the quality characteristics and antioxidant activities of 'Sulgidduk' added with chicory (Cichrium intybus $\mathbf{L}$.) powder during storage. Chicory powder was added to 'Sulgidduk' in concentrations of $1 \%, 3 \%$, or $5 \%$ of rice powder, and the 'Sulgidduk' was stored at $20^{\circ} \mathrm{C}$ for 3 days. Immediately after preparation, the moisture content of the 'Sulgidduk' increased due to the addition of chicory. During storage, the samples in the $5 \%$ additive group showed the least moisture content. Immediately after manufacture and during storage, no change was observed in the sugar content. The sugar content decreased further with the addition of chicory, but did not show much difference during storage. The $\mathbf{p H}$ immediately after manufacture was the lowest in the 5\% additive group and decreased during storage. The addition of chicory increased the Hunter color system $L$ value, but decreased the a and $b$ values. Analysis of the texture properties using a texture profile analyzer showed that the hardness and chewiness were the lowest in the $5 \%$ additive group and that the change in these properties during storage was smallest in the $5 \%$ additive group. These properties showed the opposite tendency to the moisture content. The total phenolic content, DPPH radical scavenging activity, and SOD-like activity, which represent the antioxidant activity, increased with the amount of chicory added, and showed a small reduction in the $5 \%$ chicory additive group during storage. From these results, the addition of chicory powder in 'Sulgidduk' has positive effects on its storage quality and antioxidant activities.
\end{abstract}

Key words : Cichrium intybus L., Sulgidduk, storage, quality characteristics, antioxidant activities

\begin{abstract}
서 론
치커리(Cichorium intybus L.)는 국화과에 속하는 1-2년생 초본으로 지중해 연안, 유럽, 러시아 등을 원산지로 하며, 국 내에서는 중부지방과 대관령 등에서 재배되고 있다. 치커리
\end{abstract}

\begin{abstract}
는 다양한 약리작용이나 기호식품으로 활용되는데, 유럽에서 치커리의 뿌리는 이뇨, 강장, 피를 맑게 하는데 등에 사용되 고, 꽃은 중추신경계의 흥분제로 쓰이기도 하며, 중국에서는 기관지염, 간염, 황달 등의 약재로 사용되어왔다(Hwang과 Park, 2005). 우리나라는 예로부터 치커리 뿌리를 볶고 달여
\end{abstract}

\footnotetext{
*Corresponding author. E-mail : mrkim@cnu.ac.kr, Phone : +82-42-821-6837, Fax : +82-42-821-8671

${ }^{\ddagger}$ These authors contributed equally to this work.

Received 02 April 2020; Revised 04 June 2020; Accepted 29 June 2020.

Copyright (c) The Korean Society of Food Preservation.

This is an Open Access article distributed under the terms of the Creative Commons Attribution Non-Commercial License (http://creativecommons.org/licenses/by-nc/4.0) which permits unrestricted non-commercial use, distribution, and reproduction in any medium, provided the original work is properly cited.
} 
서 차로 많이 이용해 왔으며, 잎은 주로 쌈채소로 섭취해왔다 (Hong 등, 1998). 치커리의 성분에 대한 약리효과 및 생리활 성으로는 치커리에서 쓴맛을 내는 inrervene이 소화를 촉진 하고 혈관을 강화해주며(Hwang과 Park, 2005), 치커리에 셀레 늄이나 비타민 C, tocopherol뿐만 아니라 pyrogallol, catechin. e-vanilic acid, benzoic acid 등의 페놀성 물질이 많이 함유되 어 있어서 높은 항산화 활성을 가진다(Khalaf 등, 2018; Kim 등, 1999). 또한 식이섬유가 풍부해 장 기능 개선효과가 있고 (Shin 등, 2014), 치커리 이눌린과 올리고당으로 인해 당뇨병 개선 및 혈당에 도움을 준다고 한다(Jeong, 2003).

식생활의 서구화와 식습관의 패턴 변화로 인해 국내 쌀 소 비량이 감소함에 따라 쌀의 고부가가치 산업으로 쌀 가공식 품 산업의 활성화 방안이 마련되었다. 최근 밀가루를 멀리하 고 웰빙을 추구하는 소비 트렌드가 도래되었는데, 쌀 가공식 품이 가지는 고유의 맛과 질감으로 쌀 가공식품의 활용이 증 대될 것으로 보이며, 그 중 소비가 가장 많은 떡(19.1\%)의 다양한 활용이 기대된다(aT, 2018). 떡은 곡물가루를 주원료 로 하여 만드는 우리나라 전통음식으로, 찌는 떡의 일종인 설기떡은 쌀가루와 물을 섞어서 한 덩어리로 찐 떡으로, 흰 색의 백설기에 다양한 부재료를 넣어 만들기도 한다(Hwang 등, 2012). 그러나 곡류에 물을 넣고 호화시켜 제조하는 떡은 저장 기간이 지남에 따라 금세 건조해지고, 노화가 발생하여 섭취에 불편함이 있어 이를 개선하고자 한 연구들이 많다 (Jeon과 Kim, 2016). 트레할로스 백설기(Kim과 Noh, 2008), 올리고당 백설기(Yoo와 Kim, 2001), 효소처리 백설기(Ko, 1999), 키토산 백설기(Chong 등, 2001), 말티톨 떡(Kim 등, 2014a) 등 화학적 첨가물을 통해 저장성과 품질 특성을 개선 하고자 한 연구들이 있었으나, 최근 천연물질에 대한 선호도 가 높아지며, 복숭아 막편(Kim 등, 2014b), 아몬드 설기떡 (Beak 등, 2018), 쇠비름 설기떡(Jeon과 Kim, 2016), 다시마 설기떡(Cho와 Hong, 2006), 오미자 설기떡(Seok, 2011), 비 트잎가루 설기떡(Yoo와 Ko, 2014) 등 연구의 범위를 넓혀가 고 있다.

하지만 치커리를 설기떡에 첨가한 논문은 없는 실정이며, 치커리를 기능성 식품 소재로 첨가하여 제조한 식품 연구는 치커리 식이섬유 첨가 돈육 혼합물(Choi 등, 2015)에 그칠 정 도로 연구가 미비하다. 따라서 항산화성과 생리활성이 좋은 치커리를 설기떡에 첨가하여 떡이 가진 저장성 문제를 개선 하고, 떡의 기능성을 높이고자 하였으며, 떡을 저장하면서 품 질특성 및 항산화성 연구를 진행하였다.

\section{재료 및 방법}

\section{실험재료}

본 연구에서 쌀은 홈플러스에서 구매한 추청 경기미(An- seong, Korea)를 사용하였고, 그 외에 치커리(Happiness farm products, Chuncheon, Korea), 백설탕 및 소금(CJ Cheiljedang, Incheon, Korea)을 구매하여 사용하였다.

\section{멥쌀가루 제조}

멥쌀은 5 회 수세하고 8 시간 수침한 다음, 1 시간 동안 체에 밭쳐 물기를 제거하였다. 젖은 멥쌀은 믹서기(HMF-985, Hanil Electric, Seoul, Korea)로 마쇄하고, 20 mesh 체에 두 번 내 려 고운 가루 형태로 사용하였다.

\section{치커리 분말 제조}

치커리는 3 회 수세하고 $-70^{\circ} \mathrm{C}$ 의 Deep freezer(DF9020, Ilshin Lab Co., Ltd., Yangju, Korea)에 3일 동안 동결한 후, 동결건조기(SW-UF-400P, Samwon Freezing Engineering Co., Busan, Korea)에 5일 동안 건조시킨 것을 믹서기(HMF985, Hanil Electric)로 30초씩 2회 마쇄 후 20 mesh 체에 내 려 사용하였다.

\section{치커리 설기떡 제조 및 저장 조건}

치커리 설기떡의 재료 배합비는 예비실험을 통해 Table 1 과 같이 설정하였고, 치커리 분말의 첨가량은 관능검사를 통 해 젖은 쌀가루 중량의 $1,3,5 \%$ 로 선정하였다. 치커리 설기 떡은 쌀가루, 치커리 분말, 물, 소금을 볼에 넣고, 5 분간 손으 로 비벼 잘 섞이게 한 다음 20 mesh 체에 내리고, 찌기 직전 설탕을 넣고 잘 섞어준 후에 다시 체에 내렸다. 실리콘 깔개 를 깐 대나무 찜기(지름 $23 \mathrm{~cm}$, 높이 $4 \mathrm{~cm}$ )에 섞은 쌀가루를 $2.5 \mathrm{~cm}$ 높이로 평평하게 깐 후, $2 \mathrm{~cm} \times 2 \mathrm{~cm}$ 칼금을 그었다. 찜 시루에 물 $1.7 \mathrm{~L}$ 를 넣고 물이 끓으면 대나무 찜기를 올려 놓고 20 분간 센 불에서 찌다가, 불을 끄고 5 분간 뜸을 들인 다. 제조된 떡은 30 분간 면보를 덮어 식인 후 각 시료의 가장

Table 1. Ingredients of 'Sulgidduk' added with different amounts of Cichrium intybus L.

\begin{tabular}{ccccc}
\hline Ingredient $(\mathrm{g})$ & Control & $1 \%{ }^{1)}$ & $3 \%$ & $5 \%$ \\
\hline Rice powder & 600 & 594 & 582 & 570 \\
Chicory powder & 0 & 6 & 18 & 30 \\
Water & 96 & 96 & 96 & 96 \\
Sugar & 60 & 60 & 60 & 60 \\
Salt & 6 & 6 & 6 & 6 \\
\hline Total & 762 & 762 & 762 & 762 \\
\hline
\end{tabular}

${ }^{1)} 1 \%$, 'Sulgidduk' added with $1 \%$ Cichorium intybus L. in weight of rice powder; 3\%, 'Sulgidduk' added with 3\%, Cichorium intybus L. in weight of rice powder; $5 \%$, 'Sulgidduk' added with 5\% Cichorium intybus L. in weight of rice powder. 
자리를 제외한 가운데 부분을 시료로 사용하였다. 저장성 실 험을 위해 시료를 통에 밀봉한 후 $20 \pm 2^{\circ} \mathrm{C}$ 에서 30 분, 24 시간, 48시간, 72 시간 저장하면서 실험하였다. 이화학적 품질특성 은 0-3일 차에 실험을 진행하였고, 항산화 특성은 0-2일 차에 실험을 진행하였다.

\section{수분함량 측정}

설기떡의 수분함량 측정은 시료 $3 \mathrm{~g}$ 을 칭량접시에 칭량하 고, 건조기에서 $105^{\circ} \mathrm{C}$ 상압가열건조법(AOAC, 1990)을 통해 측정하였다.

\section{당도 및 환원당 측정}

시료 $5 \mathrm{~g}$ 과 증류수 $45 \mathrm{~mL}$ 를 Bag Mixer(Model 400, Interscience, Woburn, MA, USA)로 균질화(speed 7, $2 \mathrm{~min}$ ) 하고, sonication(Powersonic 420, HwashinTech, Busan, Korea) $40^{\circ} \mathrm{C}$ 에서 20 분 동안 추출한 것을 $3,000 \mathrm{rpm}$ 의 원심분 리기(Combi 514R, Hanil, Hwaseong, Korea)로 15분간 원심 분리하여 얻은 상징액을 시료 용액으로 하였다. 당도는 당도 계(N-1E Brix 0-92\%, Atago, Tokyo, Japan)로 측정하였고, 환원당은 시료 용액을 dinitrosalicylic acid(DNS)에 의한 비 색법으로 분광광도계(UV-1800, Beckman, Fullerton, CA, USA)로 $550 \mathrm{~nm}$ 에서 흡광도를 측정한 후 glucose 함량으로 나타내었다. 표준곡선은 농도별 glucose(Duksan Pure Chemicals Co., Seoul, Korea)의 흡광도 값으로 나타내었다.

\section{$\mathrm{pH}$ 및 산도 측정}

시료 용액은 당도 및 환원당 실험에서 제조한 것을 사용하 였다. $\mathrm{pH}$ 는 시료 용액을 $\mathrm{pH}$ meter(420 Benchtop, Orion Research, Beverly, MA, USA)로 측정하였다(AOAC, 1990). 산도는 시료 용액을 $10 \mathrm{~mL}$ 를 취한 것에 $0.1 \mathrm{~N} \mathrm{NaOH}$ (Samchun, Pyeongtaek, Korea)를 첨가하여 $\mathrm{pH}$ 가 8.3에 도달 할 때까지 요구되는 $0.1 \mathrm{~N} \mathrm{NaOH}$ 의 양을 acetic acid 함량(\%) 으로 환산하여 나타내었다.

\section{색도 측정}

시료는 $20 \mathrm{~g}$ 씩 갈아 균일하게 섞은 것을 페트리디쉬 $(50 \times 12 \mathrm{~mm})$ 에 $10 \mathrm{~g}$ 씩 담아 Hunter 색차계(ND-1001 DP, Nippon Denshoku Co. Ltd., Tokyo, Japan)를 사용하여 L값 (Lightness), $\mathrm{a}$ 값(Redness), $\mathrm{b}$ 값(Yellowness)을 반복 측정하여 평균값으로 나타내었다. Standard color value는 L값 81.83,a 값 $0.87, \mathrm{~b}$ 값 2.78 인 calibration plate를 표준으로 사용하였다.

\section{기계적 조직감 측정}

기계적 조직감이란 구강에서 감각적으로 판단되는 조직감
을 가능한 객관적으로 측정하기 위해 Texture analyser (TA/XT2, Stable Micro System Ltd., Godalming, England) 를 사용하여 여러 가지 조직감 성질로 나타낸 것을 말한다 (Kim 등, 2006). 시료는 $2.0 \times 2.0 \times 2.0 \mathrm{~cm}^{3}$ 의 동일한 크기로 자른 것을 probe로 2 회 연속 압착하였을 때 도출되는 힘-시 간 곡선으로부터 경도(hardness), 탄력성(springiness), 응집성 (cohesiveness), 씹힘성(chewiness), 회복력(resilience)을 측정 하여 5회 이상 반복 측정 후 그 평균값으로 나타내었다.

Texture analyser 측정 시, probe는 직경이 $25 \mathrm{~mm}$ 인 compression plate를 사용하였고, 분석조건은 pre-test speed 1.0 $\mathrm{mm} / \mathrm{s}$, test speed $1.0 \mathrm{~mm} / \mathrm{s}$, post-test speed $1.0 \mathrm{~mm} / \mathrm{s}$, 압축 시 변형률은 $8.0 \mathrm{~mm}$ 로 설정하였다.

\section{총페놀성 화합물 함량 측정}

총페놀성 화합물 함량은 페놀성 물질이 phosphomolybdic $\mathrm{acid}$ 를 환원시켜 청색으로 변화하는 정도로 구할 수 있으며, Folin-Denis법으로 측정하였다. 시료 $1.5 \mathrm{~g}$ 에 $\mathrm{MeOH} 50 \mathrm{~mL}$ 를 넣고 $25^{\circ} \mathrm{C}, 11 \times \mathrm{g}$ 의 조건에서 12 시간 동안 추출한 후, $4^{\circ} \mathrm{C}$, $4,326.7 \times g$ 에서 20 분간 원심 분리(Combi 514R, Hanil)하여 얻어진 상징액을 evaporator(N-1110, EYELA, Tokyo, Japan) 로 용매를 휘발하여 추출물만 얻었다. 추출물을 phosphatebuffered saline(PBS) buffer로 녹여 $200 \mathrm{mg} / \mathrm{mL}$ 농도의 시료 용액을 실험에 사용하였다. 시료 용액 $0.33 \mathrm{~mL}$ 에 FolinDenis 시약 $0.16 \mathrm{~mL}$ 와 $\mathrm{Na}_{2} \mathrm{CO}_{3}$ 포화용액 $0.3 \mathrm{~mL}$ 를 넣고 암 실에서 30분 반응시킨 후, 분광광도계(UV-1800, Beckman) 로 $760 \mathrm{~nm}$ 에서 흡광도를 측정하였다. 표준곡선은 농도별 tannic acid(Yakuri Pure Chemicals Co., Ltd., Kyoto, Japan) 의 흡광도 값으로 나타내었다.

\section{$\mathrm{DPPH}$ 라디칼 소거능 측정}

$\mathrm{DPPH}$ 라디칼 소거능은 자유 라디칼을 가지는 $\mathrm{DPPH}$ 가 항산화 물질의 $-\mathrm{OH}$ 기와 반응하여 자유 라디칼이 소거되는 정도로 항산화능을 평가하며, Blois법(1958)으로 측정하였다. 총페놀성 화합물 함량 실험과 동일한 방법으로 얻은 추출물 에 $\mathrm{MeOH}$ 을 첨가하여 $200 \mathrm{mg} / \mathrm{mL}$ 농도의 시료 용액을 실험 에 사용하였다. 농도별로 희석한 시료 용액 $50 \mu \mathrm{L}$ 에 $1.5 \times 10^{-4}$ mM DPPH(1,1-diphenyl-2-picryl hydrazyl) 용액 $150 \mu \mathrm{L}$ 를 넣고 30 분간 암실에서 반응시킨 뒤 분광광도계(UV-1800, Beckman)로 $515 \mathrm{~nm}$ 에서 흡광도를 측정하였다. DPPH 라디 칼 소거능(\%)은 다음 식으로 계산한 후 각 농도별 라디칼 소 거능에 대한 검량선을 그린 후, 라디칼 소거능이 $50 \%$ 가 되는 농도인 $\mathrm{IC}_{50}$ 값으로 나타내었다. 
Free radical scavenging activity $(\%)=$

$$
\frac{\mathrm{Abs}_{\text {control }}-\mathrm{Abs}_{\text {sample }}}{\mathrm{Abs}_{\text {control }}} \times 100
$$

\section{Superoxide dismutase (SOD) 유사활성 측정}

Pyrogallol은 superoxide에 의해 자동산화가 발생해 갈색 물질을 생성하는데, SOD는 자동산화를 억제하는 물질이며, $\mathrm{SOD}$ 와 같이 산화적 손상으로의 보호 정도를 알기 위하여 SOD 유사활성을 측정하였다(Marklund와 Marklund, 1974). $\mathrm{DPPH}$ 라디칼 소거능 실험에서 사용한 농도별 시료 용액 20 $\mu \mathrm{L}$ 에 Tris- $\mathrm{HCl}$ 의 완충용액 $(50 \mathrm{mM}$ Tris $+10 \mathrm{mM}$ EDTA, $\mathrm{pH}$ 8.5) $260 \mu \mathrm{L}$ 와 $7.2 \mathrm{mM}$ pyrogallol $20 \mu \mathrm{L}$ 를 넣고 $25^{\circ} \mathrm{C}$ 에서 10 분간 반응시킨 뒤 분광광도계(UV-1800, Beckman)로 420 $\mathrm{nm}$ 에서 산화된 pyrogallol의 양을 측정하였다. SOD 유사활 성(\%)은 다음 식으로 계산한 후, 각 농도별 SOD 유사활성에 대한 검량선을 그린 후, 농도를 $50 \%$ 로 낮추는데 필요한 항산 화제의 양을 $\mathrm{EC}_{50}$ 값으로 나타내었다.

$$
\text { SOD-like activity }(\%)=\frac{\mathrm{Abs}_{\text {control }}-\mathrm{Abs}_{\text {sample }}}{\mathrm{Abs}_{\mathrm{control}}} \times 100
$$

\section{통계처리}

본 실험은 모두 3회 이상 반복 측정한 결과값을 SPSS 24.0 (Statistical Package for Social Science. SPSS Inc., Chicago $\mathrm{IL}, \mathrm{USA}$ ) 프로그램의 기술통계를 통해 '평균 \pm 표준편차'의 형태로 나타내었고, 분산분석(ANOVA)을 통해 유의성 검증 을 하였으며, Duncan의 다중범위검정(Duncan's multiple range test)으로 시료 간의 유의차를 검정하였다 $(\mathrm{p}<0.05)$.

\section{결과 및 고찰}

\section{수분함량}

$20^{\circ} \mathrm{C}$ 에서 3 일 동안 저장한 치커리 분말 첨가 설기떡의 저 장 일수에 따른 수분함량 측정 결과는 Table 2 와 같다. 제조 직후 설기떡의 수분 함량은 대조군, 치커리 분말 $1 \%$ 첨가군, 치커리 분말 $3 \%$ 첨가군, 치커리 분말 $5 \%$ 첨가군이 각각 $45.97,46.60,46.91,47.74 \%$ 로 치커리 분말 첨가량이 증가할 수록 수분함량은 증가하였으나 유의적 차이는 보이지 않았다 ( $p>0.05)$. 이는 쇠비름 설기떡(Lee 등, 2015), 다시마 설기떡 (Cho와 Hong, 2006), 파프리카 설기떡(Cho 등, 2008)과 같은 경향을 보였다. 또한 식이섬유소재 떡볶이떡(Chae, 2018)에서 치커리 분말이 $10 \%$ 첨가된 떡볶이떡이 대조군보다 수분함량 이 높았다. 이러한 결과는 식이섬유와 수분 결합력에 관한 연
구(Kye, 1996)에서 채소의 식이섬유와 수분 결합력이 높은 상관관계를 가지며, 가식부 $100 \mathrm{~g}$ 에 대한 치커리의 식이섬유 소 함량은 $2 \mathrm{~g}$ 으로 멥쌀가루의 함량인 $0.6 \mathrm{~g}$ 보다 높아서 (NAAS, 2016), 치커리 첨가량이 증가할수록 수분함량이 증 가된다고 사료된다. 저장 1 일 차에는 치커리 분말 $5 \%$ 첨가군 이 $47.10 \%$ 로 가장 높았으나 유의적인 차이가 없었고 $(\mathrm{p} \geq$ $0.05), 2$ 일 차에는 대조군과 치커리 분말 $3 \%, 5 \%$ 첨가군 간 의 유의적인 차이를 보였으며 $(\mathrm{p}<0.05), 3$ 일 차에는 대조군, 치커리 분말 $1 \%$ 첨가군, 치커리 분말 $3 \%$ 첨가군, 치커리 분 말 $5 \%$ 첨가군이 각각 $38.64,39.96,41.81,43.97 \%$ 로 대조군 에 비해 치커리 분말 $3 \%, 5 \%$ 첨가군의 수분함량이 유의적으 로 높았다 $(\mathrm{p}<0.05)$. 모든 시료의 수분함량은 제조 직후와 비 교해 3 일 차에서 유의적으로 감소하였는데 $(\mathrm{p}<0.05)$, 그 감소 정도는 대조군이 $7.33 \%$ 로 가장 컸으며, 치커리 분말 $5 \%$ 첨 가군은 $3.77 \%$ 로 가장 적었다. 이는 치커리가 가지는 식이섬 유의 수분보유력으로 인해 저장기간이 증가함에 따라 치커리 첨가량이 증가할수록 떡의 수분 감소 정도가 적어진 것이라 고 사료된다. 따라서 치커리를 첨가한 떡은 저장 중에도 제조 직후의 떡 특성을 최대한 보유하며 단단해짐을 막은 것으로 보여, 치커리 첨가가 떡의 저장에 좋은 영향을 끼친 것으로 보인다.

\section{당도 및 환원당 함량}

$20^{\circ} \mathrm{C}$ 에서 3 일 동안 저장한 치커리 분말 첨가 설기떡의 저 장 일수에 따른 당도 및 환원당 측정 결과는 Table 2 와 같다. 당도는 모든 시료에서 $0.9{ }^{\circ} \mathrm{Brix}$ 로 나타나 시료 간의 유의적 인 차이가 없었다(p>0.05). 이러한 이유는 가식부 $100 \mathrm{~g}$ 당 치커리의 당류 함량은 $0 \mathrm{~g}$ 이고, 멥쌀가루의 함량은 $0.1 \mathrm{~g}$ 으로 거의 함유되어 있지 않아서(NAAS, 2016), 치커리 및 멥쌀 첨가량 변화에 따라 시료에 영향을 받지 않는 것으로 사료된 다. 쇠비름 설기떡(Lee 등, 2015)은 2.78-2.90 ${ }^{\circ} \mathrm{Brix}$ 를, 아몬 드 설기떡(Baek 등, 2018)은 9.83-11.33 ${ }^{\circ} \mathrm{Brix}$ 를 보였는데, 이는 부재료의 당류 함량 차이로 사료된다. 치커리는 혈당 및 지질대사 개선에 효과가 있기 때문에(Jeong, 2003), 당을 제 한해야하는 당뇨 환자식으로 적절할 것으로 보인다. 저장 3 일 차 당도는 대조군, 치커리 분말 $1 \%$ 첨가군, 치커리 분말 $3 \%$ 첨가군, 치커리 분말 $5 \%$ 첨가군이 각각 $0.97,1.00,0.93$, $0.97{ }^{\circ} \mathrm{Brix}$ 로 저장 기간이 지남에 따라 유의적인 차이는 보이 지 않았다( $\mathrm{p}>0.05)$. 이는 저장 기간에 따라 당도가 크게 영향 을 받지 않은 것으로 사료된다.

환원당은 제조 직후에 대조군, 치커리 분말 $1 \%$ 첨가군, 치 커리 분말 $3 \%$ 첨가군, 치커리 분말 $5 \%$ 첨가군이 각각 $0.0622,0.0644,0.0644,0.0730 \%$ 로 치커리 $5 \%$ 첨가군에서 유의적으로 높았고, 저장 3 일 차에는 각각 $0.0579,0.0622$, 
Table 2. Moisture content, sugar content, reducing sugar content, pH, and acidity of 'Sulgidduk' added with different amounts of Cichrium intybus $\mathbf{L}$.

\begin{tabular}{|c|c|c|c|c|c|}
\hline & Storage day & Control & $1 \%{ }^{1)}$ & $3 \%$ & $5 \%$ \\
\hline \multirow{4}{*}{$\begin{array}{l}\text { Moisture content } \\
(\%)\end{array}$} & 0 & $45.97 \pm 1.60^{2) \mathrm{A} 4) \mathrm{NS} 5)}$ & $46.60 \pm 1.27^{\mathrm{A}}$ & $46.91 \pm 1.36^{\mathrm{A}}$ & $47.74 \pm 1.63^{\mathrm{A}}$ \\
\hline & 1 & $43.86 \pm 2.20^{\mathrm{ABNS}}$ & $44.32 \pm 1.86^{\mathrm{AB}}$ & $46.22 \pm 0.92^{\mathrm{A}}$ & $47.10 \pm 1.73^{\mathrm{A}}$ \\
\hline & 2 & $41.27 \pm 1.68^{\mathrm{BCb} 3)}$ & $41.60 \pm 0.74^{\mathrm{BCb}}$ & $44.48 \pm 1.50^{\mathrm{Aa}}$ & $46.35 \pm 1.29^{\mathrm{ABa}}$ \\
\hline & 3 & $38.64 \pm 1.94^{\mathrm{Cc}}$ & $39.96 \pm 1.73^{\mathrm{Cbc}}$ & $41.81 \pm 1.14^{\mathrm{Bab}}$ & $43.97 \pm 0.91^{\mathrm{Ba}}$ \\
\hline \multirow{4}{*}{$\begin{array}{l}\text { Sugar content } \\
\left({ }^{\circ} \text { Brix }\right)\end{array}$} & 0 & $0.90 \pm 0.10^{\mathrm{ABNS}}$ & $0.90 \pm 0.00^{\mathrm{A}}$ & $0.90 \pm 0.00^{\mathrm{AB}}$ & $0.90 \pm 0.00^{\mathrm{BC}}$ \\
\hline & 1 & $0.80 \pm 0.00^{\mathrm{BNS}}$ & $0.77 \pm 0.58^{\mathrm{B}}$ & $0.80 \pm 0.00^{\mathrm{B}}$ & $0.83 \pm 0.58^{\mathrm{C}}$ \\
\hline & 2 & $0.80 \pm 0.00^{\mathrm{Bb}}$ & $0.90 \pm 0.10^{\text {Aab }}$ & $0.83 \pm 0.58^{\mathrm{ABb}}$ & $1.00 \pm 0.00^{\mathrm{Aa}}$ \\
\hline & 3 & $0.97 \pm 0.58^{\mathrm{ANS}}$ & $1.00 \pm 0.00^{\mathrm{A}}$ & $0.93 \pm 0.12^{\mathrm{B}}$ & $0.97 \pm 0.06^{\mathrm{AB}}$ \\
\hline \multirow{4}{*}{$\begin{array}{l}\text { Reducing sugar } \\
\text { content }(\%)\end{array}$} & 0 & $0.0622 \pm 0.0019^{\mathrm{Ab}}$ & $0.0644 \pm 0.0019^{\mathrm{NSb}}$ & $0.0644 \pm 0.0019^{\mathrm{Ab}}$ & $0.0730 \pm 0.0032^{\mathrm{Aa}}$ \\
\hline & 1 & $0.0557 \pm 0.0019^{\mathrm{BNS}}$ & $0.0568 \pm 0.0032$ & $0.0568 \pm 0.0032^{\mathrm{B}}$ & $0.0644 \pm 0.0049^{\mathrm{B}}$ \\
\hline & 2 & $0.0611 \pm 0.0019^{\mathrm{ANS}}$ & $0.0654 \pm 0.0049$ & $0.6657 \pm 0.0000^{\mathrm{A}}$ & $0.0654 \pm 0.0019^{\mathrm{B}}$ \\
\hline & 3 & $0.0579 \pm 0.0037^{\mathrm{ABNS}}$ & $0.0622 \pm 0.0162$ & $0.0654 \pm 0.0019^{\mathrm{B}}$ & $0.0611 \pm 0.0019^{\mathrm{B}}$ \\
\hline \multirow{4}{*}{$\mathrm{pH}$} & 0 & $7.19 \pm 0.01^{\mathrm{Aa}}$ & $7.12 \pm 0.02^{\mathrm{Ab}}$ & $6.99 \pm 0.02^{\mathrm{Ac}}$ & $6.90 \pm 0.05^{\mathrm{Ad}}$ \\
\hline & 1 & $6.66 \pm 0.10^{\mathrm{Ba}}$ & $6.63 \pm 0.07^{\mathrm{Ba}}$ & $6.41 \pm 0.02^{\mathrm{Bb}}$ & $6.38 \pm 0.04^{\mathrm{Bb}}$ \\
\hline & 2 & $6.37 \pm 0.02^{\mathrm{Ca}}$ & $6.35 \pm 0.03^{\mathrm{Ca}}$ & $6.29 \pm 0.02^{\mathrm{Cb}}$ & $6.27 \pm 0.01^{\mathrm{Cb}}$ \\
\hline & 3 & $6.26 \pm 0.03^{\mathrm{DNS}}$ & $6.26 \pm 0.02^{\mathrm{D}}$ & $6.25 \pm 0.03^{\mathrm{C}}$ & $6.21 \pm 0.02^{\mathrm{C}}$ \\
\hline \multirow{4}{*}{ Acidity (\%) } & 0 & $0.0035 \pm 0.0007^{\mathrm{Bb}}$ & $0.0056 \pm 0.0007^{\mathrm{NSa}}$ & $0.0072 \pm 0.0110^{\mathrm{Aa}}$ & $0.0077 \pm 0.0012^{\mathrm{NSa}}$ \\
\hline & 1 & $0.0051 \pm 0.0065^{\mathrm{Bb}}$ & $0.0065 \pm 0.0004^{\mathrm{a}}$ & $0.0089 \pm 0.0004^{\mathrm{Aa}}$ & $0.0117 \pm 0.0018^{\mathrm{a}}$ \\
\hline & 2 & $0.0063 \pm 0.0007^{\mathrm{ANS}}$ & $0.0086 \pm 0.0011$ & $0.0121 \pm 0.0011^{\mathrm{A}}$ & $0.0231 \pm 0.0012$ \\
\hline & 3 & $0.0075 \pm 0.0004^{\mathrm{Ab}}$ & $0.0107 \pm 0.0011^{\mathrm{b}}$ & $0.0163 \pm 0.0015^{\mathrm{Ba}}$ & $0.0233 \pm 0.0008^{\mathrm{a}}$ \\
\hline
\end{tabular}

${ }^{1)} 1 \%$, 'Sulgidduk' added with $1 \%$ Cichorium intybus L. in weight of rice powder; $3 \%$, 'Sulgidduk' added with $3 \%$, Cichorium intybus L. in weight of rice powder; $5 \%$, 'Sulgidduk' added with $5 \%$ Cichorium intybus L. in weight of rice powder.

${ }^{2}$ Mean \pm SD $(\mathrm{n}=3)$

${ }^{3)}$ Different letters $\left({ }^{\mathrm{a}-\mathrm{d}} \mathrm{d}\right)$ within each row are significantly different $(\mathrm{p}<0.05)$.

${ }^{4)}$ Different letters $\left({ }^{\mathrm{A}-\mathrm{C}}\right)$ within each colunm are significantly different $(\mathrm{p}<0.05)$.

${ }^{5} \mathrm{NS}$, not significant.

$0.0654,0.0611 \%$ 로 제조 직후에 비해 대조군과 치커리 $1 \%$ 첨가군에서 유의적인 차이를 보이지 않았다 $(\mathrm{p}>0.05)$.

\section{$\mathrm{pH}$ 및 산도}

$20^{\circ} \mathrm{C}$ 에서 3 일 동안 저장한 치커리 분말 첨가 설기떡의 저 장 일수에 따른 $\mathrm{pH}$ 및 산도 측정 결과는 Table 2 와 같다. $\mathrm{pH}$ 는 제조 직후에 대조군, 치커리 분말 $1 \%$ 첨가군, 치커리 분말 $3 \%$ 첨가군, 치커리 분말 $5 \%$ 첨가군이 각각 $\mathrm{pH} 7.19,7.12$, $6.99,6.90$ 으로 유의적으로 감소하였다( $<<0.05)$. 이러한 결과 는 상추 설기떡(Woo 등, 2020), 아스파라거스 설기떡(Zhang 등, 2016), 깻잎 설기떡(Choi와 Kim, 2010)과 같은 경향을 보 였다. 치커리에는 맛을 내는 산성 아미노산이 가식부 $100 \mathrm{~g}$
기준, glutamic acid가 $187 \mathrm{mg}$, aspartic acid가 $184 \mathrm{mg}$ 있고 (NAAS, 2016), 대부분의 잎채소에는 유기산이 함유되어 있 어서 치커리 첨가량이 증가할수록 산성을 띠어 $\mathrm{pH}$ 가 감소한 다고 사료된다.

저장 3 일 차 $\mathrm{pH}$ 는 대조군, 치커리 분말 $1 \%$ 첨가군, 치커리 분말 $3 \%$ 첨가군, 치커리 분말 $5 \%$ 첨가군이 각각 $\mathrm{pH} 6.26$, $6.26,6.25,6.21$ 로 값은 감소하였지만 유의적인 차이는 보이 지 않았다 $(\mathrm{p}>0.05)$. 모든 시료가 저장 기간이 지남에 따라 $\mathrm{pH}$ 가 유의적으로 낮아졌다. 오미자 설기떡(Seok, 2011), 로 즈마리 및 녹차 설기떡(Gwon과 Moon, 2009)에서도 부재료 첨가량이 증가하고, 저장기간이 증가함에 따라 $\mathrm{pH}$ 가 감소하 며 같은 경향을 보였다. 다만 $\mathrm{pH}$ 의 감소 정도는 치커리 첨가 
량이 증가할수록 점차 적어졌는데, 이는 Kim과 Park(2014) 에서 단백질의 완충효과 때문이라는 보고와 상응하는 결과라 고 사료된다. 따라서 $\mathrm{pH}$ 의 변화 정도가 적은 치커리 분말 $5 \%$ 첨가군에서 품질변화가 적을 것으로 사료된다.

산도는 제조 직후에 대조군, 치커리 분말 $1 \%$ 첨가군, 치커 리 분말 $3 \%$ 첨가군, 치커리 분말 $5 \%$ 첨가군이 각각 0.0035 , $0.0056,0.0072,0.0077 \%$ 로 대조군과 첨가군 간의 유의적인 차이를 보였으며 $(\mathrm{p}<0.05)$, 저장 3 일 차의 산도값은 각각 $0.0075,0.0107,0.0163,0.0233 \%$ 로 치커리 첨가량이 증가하 고, 저장 기간이 지남에 따라 점차 증가하였다.

\section{색도}

$20^{\circ} \mathrm{C}$ 에서 3 일 동안 저장한 치커리 분말 첨가 설기떡의 저 장 일수에 따른 색도 측정 결과는 Table 3 과 같다. $\mathrm{L}$ 값은 제 조 직후에 대조군, 치커리 분말 $1 \%$ 첨가군, 치커리 분말 $3 \%$ 첨가군, 치커리 분말 $5 \%$ 첨가군이 각각 $74.21,50.51,41.41$, 32.71로 치커리 분말 첨가량이 증가함에 따라 $\mathrm{L}$ 값은 유의적 으로 감소하였고 $(\mathrm{p}<0.05)$, 이러한 결과는 상추 설기떡(Woo 등, 2020), 쑥갓 설기떡(Choi와 Lee, 2010), 아스파라거스 설 기떡(Zhang 등, 2016)과 경향이 같았다. 치커리를 첨가함에 따라 $\mathrm{L}$ 값이 유의적으로 감소한 이유는 치커리가 짙은 녹색을 띠기 때문에 첨가량을 증가함에 따라 시료가 점차 어두워짐
에 따른 결과라고 사료된다. 저장 3 일 차에 $\mathrm{L}$ 값은 각각 $76.17,55.18,48.87,41.13$ 으로 각 시료의 L값은 제조 직후에 비해 유의적으로 증가하였다 $(\mathrm{p}<0.05)$.

$\mathrm{a}$ 값은 제조 직후에 대조군, 치커리 분말 $1 \%$ 첨가군, 치커 리 분말 $3 \%$ 첨가군, 치커리 분말 $5 \%$ 첨가군이 각각 -2.16 , $-0.99,0.16,0.24$ 로 유의적으로 증가하였고( $\mathrm{p}<0.05)$, 이는 곰 취 설기떡(Kang과 Kim, 2011), 아스파라거스 설기떡(Zhang 등, 2016), 양배추 설기떡(Yang, 2009)과 경향이 같았다. 저 장 3 일 차에는 각각 $-1.88,-1.01,0.16,0.25$ 로 치커리 첨가가 늘어남에 따라 유의적으로 증가하였고 $(\mathrm{p}<0.05)$, 이는 제조 직후에 비해 3 일 차에서 $1 \%$ 첨가군을 제외하고 유의적으로 증가하였다 $(\mathrm{p}<0.05)$.

$\mathrm{b}$ 값은 제조 직후에 대조군, 치커리 분말 $1 \%$ 첨가군, 치커 리 분말 $3 \%$ 첨가군, 치커리 분말 $5 \%$ 첨가군이 각각 7.05 , $18.20,19.57,20.35$ 로 유의적으로 증가하였고 $(\mathrm{p}<0.05)$, 녹차 및 로즈마리 설기떡(Gwon과 Moon, 2009), 아스파라거스 설 기떡(Zhang 등, 2016), 쑥 설기떡(Ahn, 2019), 녹차 설기떡 (Hong 등, 1999), 양배추 설기떡(Yang, 2009)과 경향이 같았 다. 저장 3 일 차에는 각각 $6.49,17.35,19.45,20.66$ 으로 제조 직후에 비해 3 일 차에서 $\mathrm{b}$ 값은 $5 \%$ 첨가군을 제외하고 대체 적으로 감소함을 보였다 $(\mathrm{p}<0.05)$.

이와 같은 결과를 통해, 설기떡에 첨가되는 부재료의 특

Table 3. Color values of 'Sulgidduk' added with different amounts of Cichrium intybus L.

\begin{tabular}{|c|c|c|c|c|c|c|}
\hline & & Storage day & Control & $1 \%{ }^{1)}$ & $3 \%$ & $5 \%$ \\
\hline \multirow{12}{*}{ Color value } & \multirow{4}{*}{$\mathrm{L}$} & 0 & $74.21 \pm 0.35^{2) \mathrm{B} 4) \mathrm{a} 3)}$ & $50.51 \pm 1.00^{\mathrm{Cb}}$ & $41.41 \pm 0.46^{\mathrm{Cc}}$ & $32.71 \pm 0.61^{\mathrm{Bd}}$ \\
\hline & & 1 & $74.11 \pm 0.18^{\mathrm{Ba}}$ & $52.20 \pm 0.69^{\mathrm{BCb}}$ & $47.20 \pm 0.19^{\mathrm{Bc}}$ & $34.01 \pm 1.28^{\mathrm{Bd}}$ \\
\hline & & 2 & $74.67 \pm 0.38^{\mathrm{ABa}}$ & $54.83 \pm 2.66^{\mathrm{ABb}}$ & $48.00 \pm 0.76^{\mathrm{ABc}}$ & $40.67 \pm 0.33^{\mathrm{Ad}}$ \\
\hline & & 3 & $76.17 \pm 1.82^{\mathrm{Aa}}$ & $55.18 \pm 0.43^{\mathrm{Ab}}$ & $48.87 \pm 0.32^{\mathrm{Ac}}$ & $41.13 \pm 0.55^{\mathrm{Ad}}$ \\
\hline & \multirow{4}{*}{$\mathrm{a}$} & 0 & $-2.16 \pm 0.03^{\mathrm{Bd}}$ & $-0.99 \pm 0.01^{\mathrm{NS} 5) \mathrm{c}}$ & $0.16 \pm 0.02^{\mathrm{Bb}}$ & $0.24 \pm 0.01^{\mathrm{Ba}}$ \\
\hline & & 1 & $-1.91 \pm 0.02^{\mathrm{Ac}}$ & $-0.87 \pm 0.10^{b}$ & $0.16 \pm 0.02^{\mathrm{Aa}}$ & $0.24 \pm 0.01^{\mathrm{Aa}}$ \\
\hline & & 2 & $-1.92 \pm 0.03^{\mathrm{Ac}}$ & $-1.01 \pm 0.09^{\mathrm{b}}$ & $0.17 \pm 0.06^{\mathrm{Aa}}$ & $0.25 \pm 0.04^{\mathrm{Aa}}$ \\
\hline & & 3 & $-1.88 \pm 0.42^{\mathrm{Ac}}$ & $-1.01 \pm 0.19^{b}$ & $0.16 \pm 0.03^{\mathrm{Aa}}$ & $0.25 \pm 0.02^{\mathrm{Aa}}$ \\
\hline & \multirow{4}{*}{$\mathrm{b}$} & 0 & $7.05 \pm 0.03^{\mathrm{Bd}}$ & $18.20 \pm 0.25^{\mathrm{Ac}}$ & $19.57 \pm 0.14^{\mathrm{NSb}}$ & $20.35 \pm 0.37^{\mathrm{NSa}}$ \\
\hline & & 1 & $7.11 \pm 0.22^{\mathrm{Ad}}$ & $17.82 \pm 0.66^{\mathrm{ABc}}$ & $19.29 \pm 0.53^{b}$ & $20.45 \pm 0.32^{\mathrm{a}}$ \\
\hline & & 2 & $7.07 \pm 0.21^{\mathrm{Ad}}$ & $17.36 \pm 0.32^{\mathrm{Bc}}$ & $19.24 \pm 0.57^{\mathrm{b}}$ & $20.76 \pm 0.09^{\mathrm{a}}$ \\
\hline & & 3 & $6.49 \pm 0.11^{\mathrm{Ad}}$ & $17.35 \pm 0.20^{\mathrm{Bc}}$ & $19.45 \pm 0.26^{\mathrm{b}}$ & $20.66 \pm 0.49^{\mathrm{a}}$ \\
\hline
\end{tabular}

${ }^{1)} 1 \%$, 'Sulgidduk' added with $1 \%$ Cichorium intybus L. in weight of rice powder; $3 \%$, 'Sulgidduk' added with $3 \%$, Cichorium intybus L. in weight of rice powder; $5 \%$, 'Sulgidduk' added with $5 \%$ Cichorium intybus L. in weight of rice powder.

${ }^{2)}$ Mean \pm SD $(\mathrm{n}=3)$

${ }^{3)}$ Different letters $\left({ }^{a-d}\right)$ within each row are significantly different $(\mathrm{p}<0.05)$.

${ }^{4}$ Different letters $\left({ }^{A-C}\right)$ within each colunm are significantly different $(\mathrm{p}<0.05)$.

${ }^{5} \mathrm{NS}$, not significant. 
성에 따라 색도가 다양한 결과로 나타났기에 치커리 설기떡 의 색도 결과는 치커리 고유의 특성에 의한 결과라고 사 료된다.

\section{기계적 조직감}

$20^{\circ} \mathrm{C}$ 에서 3 일 동안 저장한 치커리 분말 첨가 설기떡의 저 장 일수에 따른 기계적 조직감 측정 결과는 Table 4와 같다.

경도는 제조 직후에 대조군, 치커리 분말 $1 \%$ 첨가군, 치커 리 분말 $3 \%$ 첨가군, 치커리 분말 $5 \%$ 첨가군이 각각 374.25 , $326.47,273.03,215.54 \mathrm{~g}$ 으로 유의적으로 감소하였다 $(\mathrm{p}<0.05)$. 이는 쇠비름 설기떡(Lee 등, 2015), 다시마 설기떡 (Cho와 Hong, 2006), 파프리카 설기떡(Cho 등, 2008), 식이 섬유소재 떡볶이떡(Chae, 2018)과 같은 경향을 보였다. 다음
연구들은 경도의 경향이 수분함량과 반대 경향을 보였다. 아 몬드 설기떡(Baek 등, 2018) 연구에서 대조군이 첨가군에 비 해 상대적으로 멥쌀 첨가량이 많아 탄수화물 함량이 높기에 조직이 조밀하게 구성됨에 따라 대조군의 경도가 높다고 보 고하였다. 가식부 $100 \mathrm{~g}$ 기준으로 멥쌀의 탄수화물 함량은 $78.5 \mathrm{~g}$, 치커리의 탄수화물 함량은 $2.95 \mathrm{~g}(\mathrm{NAAS}, 2016)$ 이기 에 대조군의 탄수화물 함량이 더 많아 경도가 높다는 것을 알 수 있다. 저장 3 일 차의 경도는 대조군, 치커리 분말 $1 \%$ 첨가군, 치커리 분말 $3 \%$ 첨가군, 치커리 분말 $5 \%$ 첨가군이 각각 $2,385.28,2,054.23,1,586.64,861.03 \mathrm{~g}$ 으로 저장 기간 이 증가함에 따라 각 시료의 경도는 유의적으로 증가하였다 $(\mathrm{p}<0.05)$. 이는 떡의 저장 기간이 증가함에 따라 점차 감소하 는 수분함량에 의해 떡이 점차 굳고, 단단해짐에 따라 경도는

Table 4. Texture characteristics of 'Sulgidduk' added with different amounts of Cichrium intybus L.

\begin{tabular}{|c|c|c|c|c|c|}
\hline & Storage day & Control & $1 \%{ }^{1)}$ & $3 \%$ & $5 \%$ \\
\hline \multirow{4}{*}{ Hardness (g) } & 0 & $374.25 \pm 21.84^{2) \mathrm{D} 4) \mathrm{a} 3)}$ & $326.47 \pm 18.94^{\mathrm{Db}}$ & $273.03 \pm 6.34^{\mathrm{Dc}}$ & $215.54 \pm 4.00^{\mathrm{Dd}}$ \\
\hline & 1 & $884.34 \pm 37.55^{\mathrm{Ca}}$ & $717.22 \pm 48.66^{\mathrm{Cb}}$ & $522.98 \pm 20.28^{\mathrm{Cc}}$ & $366.14 \pm 18.06^{\mathrm{Cd}}$ \\
\hline & 2 & $1,498.44 \pm 49.16^{\mathrm{Ba}}$ & $1,233.97 \pm 80.15^{\mathrm{Bb}}$ & $893.85 \pm 36.49^{\mathrm{Bc}}$ & $547.74 \pm 39.05^{\mathrm{Bd}}$ \\
\hline & 3 & $2,385.28 \pm 110.31^{\mathrm{Aa}}$ & $2,054.23 \pm 29.32^{\mathrm{Ab}}$ & $1,586.64 \pm 44.25^{\mathrm{Ac}}$ & $861.03 \pm 37.73^{\mathrm{Ad}}$ \\
\hline \multirow{4}{*}{ Springness } & 0 & $0.90 \pm 0.01^{\mathrm{Ab}}$ & $0.90 \pm 0.02^{\mathrm{NSb}}$ & $0.95 \pm 0.02^{\mathrm{Aa}}$ & $0.94 \pm 0.01^{\mathrm{Ba}}$ \\
\hline & 1 & $0.83 \pm 0.08^{\text {BNS5) }}$ & $0.89 \pm 0.06$ & $0.85 \pm 0.07^{\mathrm{B}}$ & $0.92 \pm 0.04^{\mathrm{BC}}$ \\
\hline & 2 & $0.82 \pm 0.01^{\mathrm{Bc}}$ & $0.93 \pm 0.06^{\mathrm{a}}$ & $0.85 \pm 0.04^{\mathrm{Bbc}}$ & $0.88 \pm 0.04^{\mathrm{Cab}}$ \\
\hline & 3 & $0.92 \pm 0.02^{\text {Aab }}$ & $0.91 \pm 0.08^{b}$ & $0.95 \pm 0.05^{\mathrm{Aab}}$ & $0.98 \pm 0.01^{\mathrm{Aa}}$ \\
\hline \multirow{4}{*}{ Cohensiveness } & 0 & $0.74 \pm 0.01^{\mathrm{Ab}}$ & $0.74 \pm 0.01^{\mathrm{Ab}}$ & $0.76 \pm 0.01^{\mathrm{Aa}}$ & $0.76 \pm 0.01^{\mathrm{Aa}}$ \\
\hline & 1 & $0.62 \pm 0.12^{\mathrm{Bb}}$ & $0.57 \pm 0.05^{\mathrm{Cb}}$ & $0.74 \pm 0.01^{\mathrm{ABa}}$ & $0.74 \pm 0.01^{\mathrm{BCa}}$ \\
\hline & 2 & $0.73 \pm 0.00^{\mathrm{ANS}}$ & $0.75 \pm 0.03^{\mathrm{A}}$ & $0.74 \pm 0.02^{\mathrm{AB}}$ & $0.73 \pm 0.02^{\mathrm{C}}$ \\
\hline & 3 & $0.71 \pm 0.01^{\mathrm{Abc}}$ & $0.68 \pm 0.04^{\mathrm{Bc}}$ & $0.73 \pm 0.02^{\mathrm{Bab}}$ & $0.75 \pm 0.01^{\mathrm{ABa}}$ \\
\hline \multirow{4}{*}{ Chewiness } & 0 & $242.90 \pm 28.71^{\mathrm{Da}}$ & $218.21 \pm 14.10^{\mathrm{Da}}$ & $184.98 \pm 19.76^{\mathrm{Db}}$ & $155.29 \pm 3.00^{\mathrm{Dc}}$ \\
\hline & 1 & $582.11 \pm 134.35^{\mathrm{Ca}}$ & $422.36 \pm 23.09^{\mathrm{Cb}}$ & $324.09 \pm 3.82^{\mathrm{Cc}}$ & $250.39 \pm 15.12^{\mathrm{Cc}}$ \\
\hline & 2 & $895.94 \pm 26.55^{\mathrm{Ba}}$ & $669.54 \pm 64.73^{\mathrm{Bb}}$ & $563.86 \pm 19.31^{\mathrm{Bc}}$ & $353.35 \pm 43.33^{\mathrm{Bd}}$ \\
\hline & 3 & $1,559.42 \pm 136.07^{\mathrm{Aa}}$ & $1,268.88 \pm 153.74^{\mathrm{Ab}}$ & $1,108.62 \pm 153.74^{\mathrm{Ac}}$ & $1,108.62 \pm 66.67^{\mathrm{Ad}}$ \\
\hline \multirow{4}{*}{ Resillience } & 0 & $0.58 \pm 0.01^{\mathrm{Ba}}$ & $0.54 \pm 0.02^{\mathrm{Bb}}$ & $0.60 \pm 0.01^{\mathrm{Ca}}$ & $0.54 \pm 0.01^{\mathrm{Db}}$ \\
\hline & 1 & $0.62 \pm 0.04^{\mathrm{ANS}}$ & $0.65 \pm 0.02^{\mathrm{A}}$ & $0.64 \pm 0.02^{\mathrm{B}}$ & $0.63 \pm 0.02^{\mathrm{C}}$ \\
\hline & 2 & $0.59 \pm 0.01^{\mathrm{ABc}}$ & $0.64 \pm 0.03^{\mathrm{Ab}}$ & $0.69 \pm 0.01^{\mathrm{Aa}}$ & $0.66 \pm 0.02^{\mathrm{Bb}}$ \\
\hline & 3 & $0.56 \pm 0.01^{\mathrm{Bd}}$ & $0.62 \pm 0.01^{\mathrm{Ac}}$ & $0.69 \pm 0.04^{\mathrm{Ab}}$ & $0.74 \pm 0.01^{\mathrm{Aa}}$ \\
\hline
\end{tabular}

${ }^{1)} 1 \%$, 'Sulgidduk' added with $1 \%$ Cichorium intybus L. in weight of rice powder; 3\%, 'Sulgidduk' added with 3\%, Cichorium intybus L. in weight of rice powder; $5 \%$, 'Sulgidduk' added with $5 \%$ Cichorium intybus L. in weight of rice powder.

${ }^{2)}$ Mean \pm SD $(\mathrm{n}=3)$.

${ }^{3)}$ Different letters $\left({ }^{a-d}\right)$ within each row are significantly different $(p<0.05)$.

${ }^{4)}$ Different letters $\left({ }^{A-D}\right)$ within each colunm are significantly different $(\mathrm{p}<0.05)$.

${ }^{5} \mathrm{NS}$, not significant. 
증가하였다고 사료된다. 모든 시료의 경도는 제조 직후와 비 교해 3 일 차에서 유의적으로 증가하였는데 $(\mathrm{p}<0.05)$, 그 증가 정도는 대조군이 $2011.03 \mathrm{~g}$ 으로 가장 컸으며, 치커리 분말 $5 \%$ 첨가군은 $645.49 \mathrm{~g}$ 으로 가장 적었다. 경도의 증가 정도가 적다는 것은 저장 기간동안 덜 단단해지고, 제조 직후 떡의 부드러움을 최대한 유지하고 있는 것을 의미하므로, 치커리 분말 $5 \%$ 첨가군은 대조군에 비해 떡의 보존성이 좋으며, 치 커리가 설기떡의 저장성을 증대시켜준다고 사료된다. 또한, 저장 기간에 따른 결과도 쇠비름 설기떡(Lee 등, 2015), 다시 마 설기떡(Cho와 Hong, 2006), 파프리카 설기떡(Cho 등, 2008)과 같은 경향을 보이며, 부재료 첨가가 저장성 증가에 영향을 미침을 보였다.

탄력성은 제조 직후에 대조군, 치커리 분말 $1 \%$ 첨가군, 치 커리 분말 $3 \%$ 첨가군, 치커리 분말 $5 \%$ 첨가군이 각각 0.90 , $0.90,0.95,0.94$ 로 대체적으로 증가하는 경향을 나타냈지만 $(\mathrm{p}<0.05)$, 저장 3 일 차에는 제조 직후와 비교해 유의적인 차 이를 보이지 않았다( $\mathrm{p}>0.05)$. 응집성은 제조 직후에 대조군, 치커리 분말 $1 \%$ 첨가군, 치커리 분말 $3 \%$ 첨가군, 치커리 분 말 $5 \%$ 첨가군이 각각 $0.74,0.74,0.76,0.76$ 으로 치커리 $3 \%$ 이상 첨가군에서 탄력성이 높게 나타났고 $(\mathrm{p}<0.05)$, 저장 3 일 차에서도 같은 경향을 보였다 $(\mathrm{p}<0.05)$. 씹힘성은 제조 직후 에 대조군, 치커리 분말 $1 \%$ 첨가군, 치커리 분말 $3 \%$ 첨가군, 치커리 분말 $5 \%$ 첨가군이 각각 $242.90,218.21,184.98$, 155.29 로 치커리 첨가에 따라 유의적으로 감소하였는데, 이 러한 경향은 경도와 일치하였으며, 대부분의 연구에서도 경 도와 씹힘성이 같은 경향을 보였다.

회복력은 제조 직후에 치커리 첨가에 따른 경향을 보이지 않았고 $(\mathrm{p}>0.05)$, 저장 3 일 차에는 제조 직후에 비해 첨가군에 서 유의적인 증가를 보였다( $\mathrm{p}<0.05)$.

다음의 조직감 척도들은 설기떡의 수분함량과 밀접한 관 련이 있다고 생각된다. 특히 경도, 씹힘성은 수분함량에 대한 영향으로 수분함량과 반대 경향을 보이며, 치커리를 첨가할 수록 저장성이 개선됨을 보였다.

\section{총페놀성 화합물의 함량}

$20^{\circ} \mathrm{C}$ 에서 2 일 동안 저장한 치커리 분말 첨가 설기떡의 저 장 일수에 따른 총페놀성 화합물 함량 결과는 Fig. 1과 같다. 제조 직후에 대조군, 치커리 분말 $1 \%$ 첨가군, 치커리 분말 $3 \%$ 첨가군, 치커리 분말 $5 \%$ 첨가군이 각각 $1.0382,1.2749$, $1.3712,1.4333 \mathrm{mg} / \mathrm{mL}$ 로 치커리 $5 \%$ 첨가군이 유의적으로 가장 높았다 $(\mathrm{p}<0.05)$. 이는 Khalaf 등(2018)에서 $50 \%$ 에탄올 로 추출한 치커리 잎 분말의 총페놀성 화합물 함량은 865.91 mg GAE/100 g(DW), Lee와 Lee(1994)에서 멥쌀의 총페놀 성 화합물 함량은 $170 \mathrm{mg} \mathrm{TAE} / 100 \mathrm{~g}(\mathrm{DW})$ 으로 치커리에 총

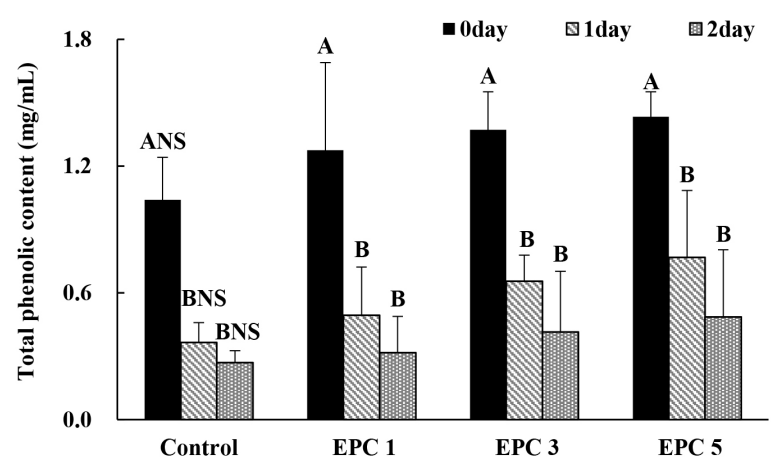

Fig. 1. Total phenol contents of 'Sulgidduk' added with different amount of Cichrium intybus L..

Values represent the mean $\pm S D(n=3)$. Means with different letters $\left({ }^{A, B}\right)$ above a bar are significantly different at $\mathrm{p}<0.05$.

NS, not significant.

페놀성 화합물이 더 많이 함유되어 치커리 첨가량이 증가할 수록 총페놀성 화합물 함량이 증가되는 것으로 사료된다. 이 는 가시파래 설기떡(Kim 등, 2019), 쑥 설기떡(Anh, 2019), 아스파라거스 설기떡(Zhang 등, 2016)과 같은 경향을 보였 다. 저장 2 일 차에는 각각 $0.2691,0.3164,0.4138,0.4855$ $\mathrm{mg} / \mathrm{mL}$ 로 제조 직후에 비해 각 시료의 총페놀성 화합물 함량 이 유의적으로 감소하였는데 $(\mathrm{p}<0.05)$, 이는 치커리 잎에 함 유되어 있던 chlorogenic acid, e-vanillic acid, catechin, ellagic acid, benzoic acid 등의 항산화성을 띠는 페놀성 화합 물들이 저장 기간이 길어질수록 감소하여 총페놀성 화합물 함량이 감소한다고 사료된다(Khalaf 등, 2018). 이는 복숭아 막편(Shim 등, 2014)과 같은 경향을 보였다. 또한 제조 직후 에 비해 2일 차에서 감소한 비율은 대조군이 $74.10 \%$ 로 가장 컸고, 치커리 $5 \%$ 첨가군이 $66.13 \%$ 로 가장 적었다. 이러한 결 과로 보아 치커리를 첨가할수록 항산화성이 높았으며, 저장 하는 동안에 항산화 물질의 감소가 가장 적었기에, 치커리 설 기떡을 제조함으로써 항산화성이 높고, 유지가 잘 되는 건강 기능성 떡의 제조에 적합할 것으로 보인다.

\section{$\mathrm{DPPH}$ 라디칼 소거능}

$20^{\circ} \mathrm{C}$ 에서 2 일 동안 저장한 치커리 분말 첨가 설기떡의 저장 일수에 따른 $\mathrm{DPPH}$ 라디칼 소거능을 $\mathrm{IC}_{50}$ 값으로 나타낸 결과는 Fig. 2 와 같다. $\mathrm{IC}_{50}$ 값은 $\mathrm{DPPH}$ 라디칼을 $50 \%$ 소거하 는 농도로, $\mathrm{IC}_{50}$ 값이 낮을수록 $\mathrm{DPPH}$ 라디칼 소거능이 높다 고 평가한다. 제조 직후에 대조군, 치커리 분말 $1 \%$ 첨가군, 치커리 분말 $3 \%$ 첨가군, 치커리 분말 $5 \%$ 첨가군의 $\mathrm{IC}_{50}$ 값은 각각 $277.5,236.3,224.7,180.6 \mathrm{mg} / \mathrm{mL}$ 로 $\mathrm{DPPH}$ 라디칼 소 거능은 유의적으로 증가하였다(p<0.05). Khalaf 등(2018)에 서 $50 \%$ 에탄올로 추출한 치커리 잎 분말의 $\mathrm{DPPH}$ 라디칼 소 


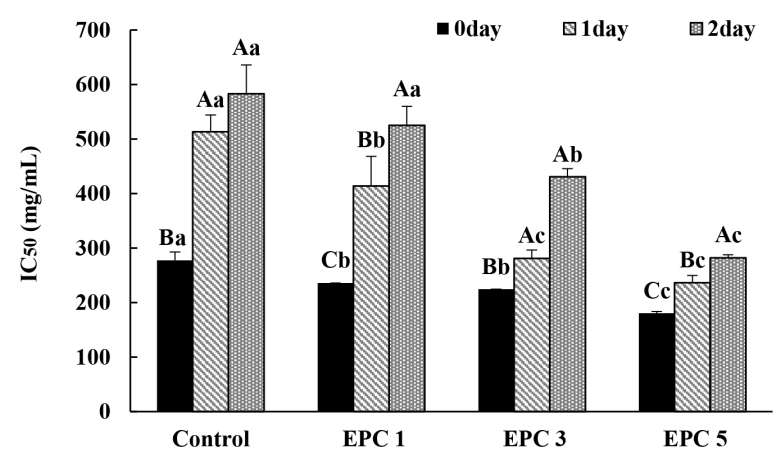

Fig. 2. DPPH radical scavenging activities of 'Sulgidduk' added with different amount of Cichrium intybus $\mathbf{L}$..

Values represent the mean \pm SD $(n=3)$. Means with different letters $\left({ }^{A-C}\right)$, $\left({ }^{\mathrm{a}-\mathrm{c}}\right)$ above a bar are significantly different at $\mathrm{p}<0.05$.

거능은 $69.73 \%$ 로 높았는데, 치커리가 페놀성 화합물이나 플 라보노이드 등의 항산화 물질을 포함함에 따라(Choi 등, 2014) 치커리를 첨가할수록 시료의 항산화성이 증가하는 것 으로 사료된다. 이는 비트잎 설기떡(Yoo와 Ko, 2014), 아스 파라거스 설기떡(Zhang 등, 2016)과 같은 경향을 보였다. 저 장 2 일 차의 $\mathrm{IC}_{50}$ 값은 각각 $583.3,525.1,430.9,282.4 \mathrm{mg} / \mathrm{mL}$ 로 제조 직후에 비해 증가하며, 항산화성이 감소함을 보였다 $(\mathrm{p}<0.05)$. 제조 직후와 비교해 3 일 차에서 $\mathrm{DPPH}$ 라디칼 소 거능이 감소한 정도는 치커리 $5 \%$ 첨가군에서 가장 적게 나 타났는데, 치커리를 첨가함으로써 저장 기간동안 항산화 물 질의 감소 정도가 적어짐을 알 수 있다.

\section{SOD 유사활성}

$20^{\circ} \mathrm{C}$ 에서 2 일 동안 저장한 치커리 분말 첨가 설기떡의 저 장 일수에 따른 $\mathrm{SOD}$ 유사활성을 $\mathrm{EC}_{50}$ 값으로 나타낸 결과는 Fig. 3 과 같다. 제조 직후에 대조군, 치커리 분말 $1 \%$ 첨가군, 치커리 분말 $3 \%$ 첨가군, 치커리 분말 $5 \%$ 첨가군의 $\mathrm{EC}_{50}$ 값은 각각 $41.69,24.98,22.59,16.97 \mathrm{mg} / \mathrm{mL}$ 로 유의적으로 감소 하였다( $\mathrm{p}<0.05)$. 이는 쇠비름 첨가 설기떡(Jeon과 Kim, 2016)과 경향이 같았다. SOD는 superoxide의 산화적 손상 반응을 억제하는 물질로써 자동산화의 억제 정도로 항산화 활성을 알 수 있다(Lee 등, 2011). 따라서 SOD 유사활성이 가장 높은 치커리 분말 $5 \%$ 첨가군이 항산화 활성이 가장 높 음을 알 수 있다. 이는 치커리에 함유된 항산화 물질들로 인 해 항산화성을 띤다고 사료된다. 저장 2 일 차에는 각각 $63.91,39.58,27.48,23.14 \mathrm{mg} / \mathrm{mL}$ 로 제조 직후에 비해 $\mathrm{EC}_{50}$ 값이 증가하며 항산화성이 낮아짐을 알 수 있다. 제조 직후와 비교해 3 일 차에서 SOD 유사활성의 감소 정도는 치커리 $5 \%$ 첨가군에서 가장 적게 나타나, 치커리를 첨가함으로써 저장 시의 항산화 물질의 감소 정도가 적어짐을 알 수 있다.

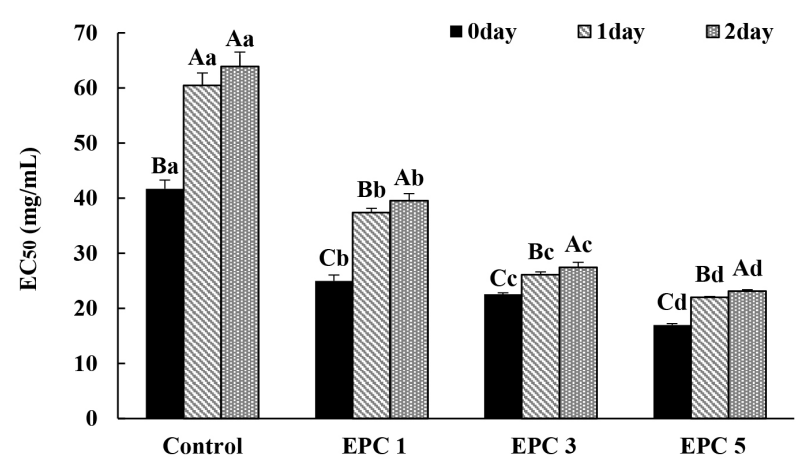

Fig. 3. Superoxide dismutase-like activity of 'Sulgidduk' added with different amount of Cichrium intybus $\mathbf{L}$..

Values represent the mean \pm SD $(n=3)$. Means with different letters $\left({ }^{A-C}\right)$, ${ }^{\mathrm{a}-\mathrm{d}}$ ) above a bar are significantly different at $\mathrm{p}<0.05$.

\section{요 약}

본 연구는 설기떡이 가지는 저장 문제를 해결하고자 다양 한 영양소를 함유하고, 수요가 증가하고 있는 치커리를 설기 떡에 $1,3,5 \%$ 비율로 첨가하여 기능성을 향상시킨 치커리 설기떡을 제조하였다. 치커리 설기떡은 $20^{\circ} \mathrm{C}$ 에 3 일 동안 저 장하면서 품질특성과 항산화성을 측정하였다. 제조 직후 치 커리 설기떡의 수분함량은 치커리를 첨가할수록 값이 증가하 였고, 저장하는 동안 각 시료의 수분함량의 감소 정도는 치커 리 $5 \%$ 첨가군에서 가장 적게 나타나 치커리로 인해 떡의 수 분이 보유되었다. 제조 직후와 저장 중에도 치커리 설기떡의 당도는 유의적인 차이를 보이지 않았다. 제조 직후 환원당은 치커리 첨가량에 따라 유의적으로 증가하였지만 $(\mathrm{p}<0.05)$, 저 장 중 유의적인 차이를 보이지 않았다. 제조 직후 치커리 설 기떡의 $\mathrm{pH}$ 는 치커리를 첨가하면서 유의적으로 감소하였고, 저장 중에는 각 시료의 $\mathrm{pH}$ 가 감소하였지만, $\mathrm{pH}$ 의 감소 정도 는 치커리 $5 \%$ 첨가군에서 가장 적게 나타나 품질 변화가 가 장 적을 것으로 생각된다. 치커리를 첨가함에 따라 설기떡의 $\mathrm{L}$ 값은 유의적으로 감소하였고, $\mathrm{a}$ 값과 $\mathrm{b}$ 값은 유의적으로 증가 하였다. 저장 중 각 시료의 L값은 유의적으로 증가하였고, a 값은 대체적으로 증가하였고, $\mathrm{b}$ 값은 대체적으로 감소하였다. 제조 직후 치커리 설기떡의 경도, 씹힘성은 수분함량과 반대 경향을 보이며 유의적으로 감소하였다. 저장 중 떡은 수분함 량 감소로 조직이 점차 단단해짐에 따라 각 시료의 값은 점차 커졌지만, 치커리 $5 \%$ 첨가군에서 값의 변화가 가장 적음을 보이며, 제조 직후 시료의 조직감 특성을 가장 잘 유지한 것으 로 생각된다. 항산화 활성을 알 수 있는 총페놀성 화합물 함량, $\mathrm{DPPH}$ 라디칼 소거능, SOD 유사활성은 치커리 첨가량이 많 아질수록 증가하였으며, 저장 기간이 지남에 따라 유의적으 로 감소하였는데, 치커리 $5 \%$ 첨가군에서는 항산화 활성의 
감소 정도가 적었다. 본 연구도 치커리를 설기떡에 첨가함으 로써 설기떡의 최대 단점인 저장성이 개선되고, 항산화 활성 이 높게 유지되는 특성의 설기떡 제조가 가능하였다.

\section{Conflict of interests}

The authors declare no potential conflict of interest.

\section{ORCID}

Hyun Jin Choi https://orcid.org/0000-0001-9623-8651

Da Hee Kim https://orcid.org/0000-0003-4149-5014

Mee Ree Kim https://orcid.org/0000-0003-3813-1447

\section{References}

Ahn GJ. Quality characteristics and antioxidantive actives of Sulgidduk added mugwort powder. Culi Sci Hos Res, 25, 184-193 (2019)

AOAC. Official Methods of Analysis. 15th ed, Washington DC, USA (1990)

Baek SY, Choi CU, Kim MR. Storage characteristics and retrogradation properties of Sulgidduk added with almond powder. J Korean Soc Food Sci Nutr, 47, 638-648 (2018)

Blois MS. Antioxidant determinations by the use of a stable free radical. Nature, 181, 1199-1200 (1958)

Chae JW. Quality characteristics of dietary fiber-added frozen Toppokki Garaedduck. MS Thesis, Keimyung University, Korea, p 17 (2018)

Cho MS, Hong JS. Quality characteristics of Sulgidduk by the addition of sea tangle. Korean J Food Cook Sci, 22, 37-44 (2006)

Cho MS, Lee JS, Hong JS. Quality characteristics of Sulgidduk with paprika. Korean J Food Cook Sci, 24, 333-339 (2008)

Choi BS, Kim HY. Quality characteristics of Sulgidduk added with perilla leaves. Korean J Culi Res, 16, 299-310 (2010)

Choi EJ, Lee SM. Quality characteristics of Sulgidduk with added Ssukgat (Chrysanthemum coronarium L. var. spatiosum) powder. J East Asian Soc Dietary Life, 20, 509-515 (2010)

Choi HS, Choi YS, Choi HG, Lee JH, Kim JH, Choi YI.
Effect of dietary fiber addition on the quality characteristics of blended pork meat. Bull Anim Biotechnol, 7, 49-54 (2015)

Choi JH, Park YH, Lee SG, Lee SH, Yu MH, Lee MS, Park $\mathrm{SH}$, Lee IS, Kim HJ. Antioxidant activities and $\alpha$ glucosidase inhibition effects of chicories grown in hydroponics added with $\mathrm{Cr}^{3+}$ or selenium. J Fd Hyg Saf, 29, 53-59 (2014)

Chong HS, Park CS, No HK. Effects of chitosan on quality and shelf-life of Packsulgis added chitosan. Korean J Postharvest Sci Technol, 8, 427-433 (2001)

Gwon SY, Moon BK. The quality characteristics of Sulgidduk prepared with green tea or rosemary powder. Korean $\mathrm{J}$ Food Cook Sci, 25, 150-159 (2009)

Hong HJ, Choi JH, Choi KH, Choi SW, Rhee SJ. Quality changes of Sulgiduk added green tea powder during storage. J Korean Soc Food Sci Nutr, 28, 1064-1068 (1999)

Hong MJ, Lee GD, Kim HK, Kwon JH. Changes in functional and sensory properties of chicory roots induced by roasting processes. Korean J Food Sci Technol, 30, 413-418 (1998)

Hwang HS, Han BR, Han BJ, Jung RN. Korean Traditional Food Written by Three Generations. Gyomoon Publishing Co, Paju, Korea, p 103 (2012)

Hwang JH, Park JE. Food Material Science. Hyoil Publishing Co, Seoul, Korea, p 130-131 (2005)

Jeon MR, Kim MR. Antioxidant activities and quality characteristics of Sulgidduk added with Portulaca oleracea L.. J Korean Soc Food Sci Nutr, 45, 1447-1452 (2016)

Jeong HJ. Effects of chicory inulin and oligosaccharides on blood glucose, lipid metabolism and immune functions in streptozotocin-induced diabetic mice. MS Thesis, Daegu University, Korea, p 53 (2003)

Kang YS, Kim JS. Quality characteristics of Sulgidduk supplemented with Ligularia fischeri powder. J East Asian Soc Diet Life, 21, 277-283 (2011)

Khalaf HA, El-Saadani RM, El-Desouky AI, Abdeldaiem $\mathrm{MH}$, Elmehy ME. Antioxidant and antimicrobial activity of gamma-irradiated chicory (Cichorium intybus L.) leaves and roots. J Food Meas Charact, 12, 1843-1851 (2018)

Ko BK. Development of the method to extend shelf life of Backsulgie with enzyme treatment. Korean J Soc Food 
Sci, 15, 533-538 (1999)

Kim DH, Baek SY, Kim SJ, Kim MR. Physicochemical properties and antioxidant activities of Sulgidduk added with Enteromorpha prolifera. J Korean Soc Food Sci Nutr, 48, 1090-1097 (2019)

Kim HJ, Yoo SM, Han HM, Park BR, Han GJ. Quality characteristics of baked rice cake added with maltitol. J Korean Soc Food Sci Nutr, 43, 1068-1074 (2014a)

Kim HJ, Shim EK, Kim MR. Storage characteristics and retrogradation property of Makphyun containing peach. Korean J Food Cook Sci, 30, 531-539 (2014b)

Kim HY, Kim MR, Ko BK. Evaluation of Food Quality. Hyoil Publishing Co, Seoul, Korea, p 63-68 (2006)

Kim HY, Noh KS. Effect of trehalose on the shelf-life of Backsulgies. Korean J Food Cook Sci, 24, 912-918 (2008)

Kim JH, Park GS. Quality characteristics of kimchi added with blue crab. Korean J Culi Res, 20, 246-259 (2014)

Kim MH, Kim MC, Park JS, Park EJ, Lee JO. Determination of antioxidants contents in various plants used as tea materials. Korean J Food Sci Technol, 31, 273-279 (1999)

Korea Agro-Fisheries \& Food Trade Corp (aT). 2018 Status of Processed Food Market - Rice Cake, Korean Traditional Cookie Market. 11-1543000-002354-01 (2018)

Kye SK. Water binding capacity of vegetable fiber. Korean J Food Nutr, 9, 231-235 (1996)

Lee JH, Lee SR. Analysis of phenolic substances content in Korean plant foods. Korean J Food Sci Technol, 26, 310-316 (1994)

Lee SJ, Lee BD, Jeon MR, Kim YJ, Kim MR. Storage characteristics and retrogradation properties of Sulgidduk added with Portulaca oleracea L.. J Korean Soc Food Sci Nutr, 44, 1517-1524 (2015)

Lee YM, Bae JH, Jung HY, Kim JH, Park DS. Antioxidant activity in water and methanol extracts from Korean edible wild plants. J Korean Soc Food Sci Nutr, 40, 29-36 (2011)

Marklund S, Marklund G. Involvement of the superoxide anion radical in the autoxidation of pyrogallol and a convenient assay for superoxide dismutase. Eur J Biochem, 47, 469-474 (1974)

National Academy of Agricultural Science (NAAS). Korean Food Composition Table, 9th ed, National Academy of Agricultural Science, Seoul, Korea p 6, 164 (2016)

Shim EK, Kim HJ, Kim MR. Quality characteristics and antioxidant activities of peach Makphyun. J Korean Soc Food Sci Nutr, 43, 1724-1730 (2014)

Shin S, Park SS, Lee HM, Hur JM. Effects of fermented chicory fiber on the improvement of intestinal function and constipation. J Korean Soc Food Sci Nutr, 43, 55-59 (2014)

Seok JE. The quality characteristics and antimicrobial activity of Omija Sulgidduk. MS Thesis, Ewha Womans University, Korea, p 19-20 (2011)

Woo Y, Kim SJ, Kim MR. Quality characteristics and antioxidant activities of Sulgidduk added with Lactuca sativa. Korean J Food Cook Sci, 36, 50-57 (2020)

Yang MO. Quality characteristics of Sulgidduk added with cabbage powder. J East Asian Soc Diet Life, 19, 729735 (2009)

Yoo SS, Ko SH. Quality characteristics of Sulgidduk with beet leaf powder. Korean J Food Cook Sci, 30, 119-128 (2014)

Yoo JN, Kim YA. Effect of oligosaccharide addition on gelatinization and retrogradation of Backsulgies. Korean J Soc Food Cook Sci, 17, 156-164 (2001)

Zhang Y, Kim JH, Song KY, O HB, Kim YS. Quality characteristics and antioxidant activities of Sulgidduk with asparagus (Asparagus officinalis L.) powder. J East Asian Soc Diet Life, 26, 63-72 (2016) 